\title{
Breyten Breytenbach
}

\section{DANCING WITH WORDS TO TRACE THE RHYTHM OF SENSE}

\section{THE ZBIGNIEW HERBERT AWARD 2017 CEREMONY}

(text reviewed and brought up to date, December 2017)

I dreamt I was in the Théâtre Polski, a place hallowed by many dreams, among people much like myself, strangers exactly as I am, trying to tell them who I am and where I come from. Not a word flew from my mouth - neither bird nor butterfly or moth. Not even a cockroach. And yet they understood everything...

I had to keep going however impossible the assignment ('twalking' is the appropriate English neologism) because the contact was tenuous and I had only 12 minutes to find meaning. Was it not Ibn al-Arabi who proclaimed movement as the origin of existence? And did Robert Walser not later confirm this by saying, "perpetual movement generates morality"? But how was I then to convey my appreciation of the honour of having been invited or my affection for the hosts? To mind came an injunction my Afrikaner mentor in writing, the late Jan Rabie, taught me: "The definition of love is to keep on moving and making a noise."

Indeed there is, however paradoxical, a certain unthinking bravery in writing, a lucidity in the conviction that the light which effaces paradoxes can be brought into being, shaped in words which will be thoughts conveying meaning by sound - as the cobweb will shiver to recall movement and thereby memory even though it is the tracing of disappearance.

You write to exorcise the not-knowing - the idea of dying is still a literary conceit - while believing (or making believe) that the reality of living is trapped in the 


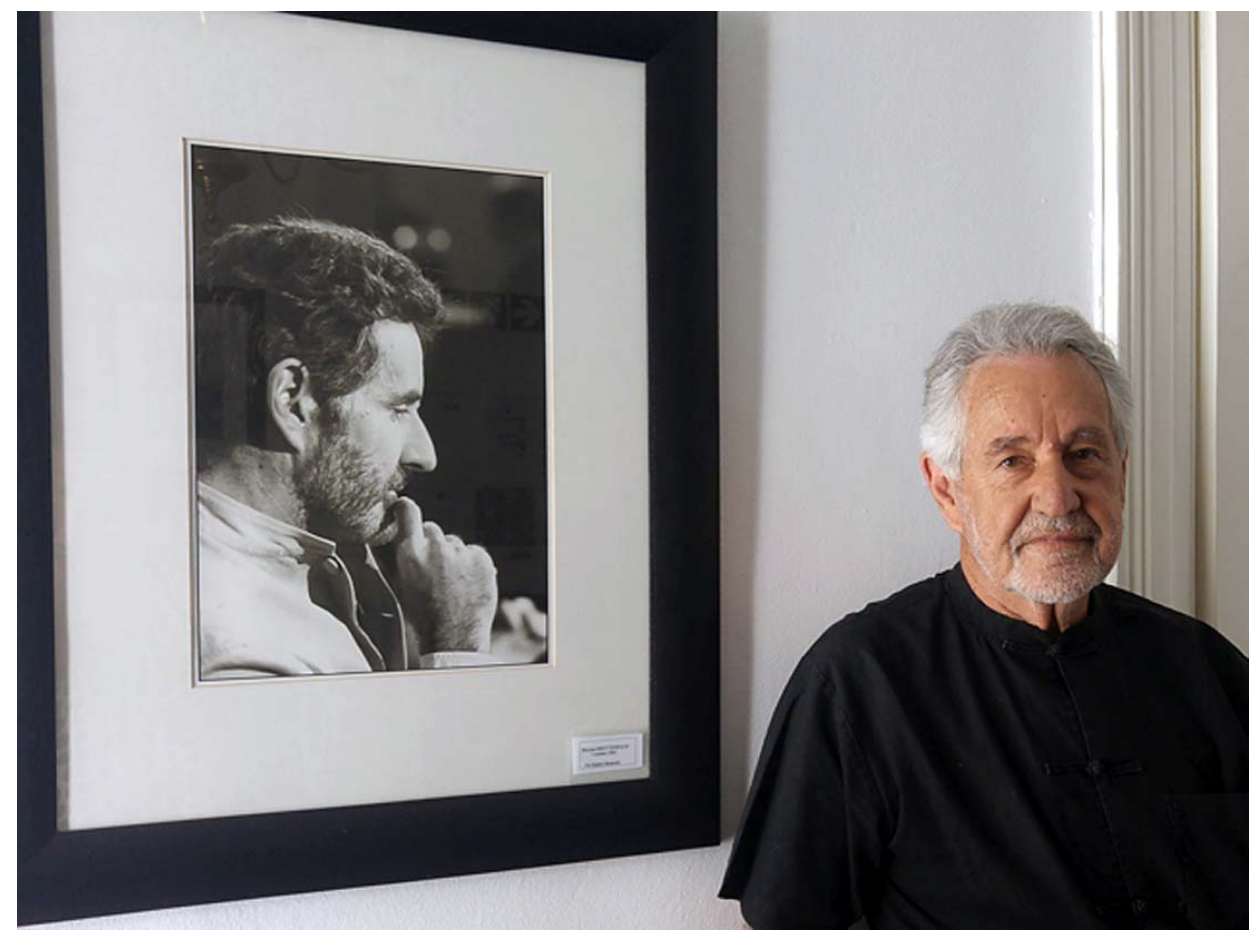

Breyten Breytenbach 
line. And then you write to exorcise the reality which came into being through your writing. And then you write (you must go on) to exorcise the intimate knowledge of dying. Maybe even of non-being. And then you write to accompany that realization, because you can do no less. And then the writing does not need to come into being for you to exist at all - for dying needs neither proof nor formulation nor echo to be.

This knowledge may impart to you a mastery of the useless: you exist in the writing.

Or: writing (will be) the inexorable unfolding of life and the infolding of dying quite beyond the self's need to act as go-between.

For me it is a trajectory of silent singing, counting and calling and naming and classifying the stones that mark the crossings.

In the late $18^{\text {th }}$ century a travel report to the far reaches of the Cape Colony - when all the world was one and only needed to be 'discovered' to exist, when humans walking upside down to escape their shadows and unicorns and King Solomon's fabulous gold mines still filled the dreams of the Enlightenment thinkers - an explorer noted that the Khoi term for 'writing' was coeroeo (at least, that is what the Europeans heard and transcribed): the same expression used for the art of imitation. Writing, it can thus be said, is an imitation of what exists. Of birds and butterflies and moths and cockroaches. Of stones found along the way.

The road has its own memories in the movement and the imagination of disappearance. And perhaps this becoming can be copied in the motionless travelling of imploding surfaces of a Giorgio Morandi painting or the flight of a Tibetan monk.

For the universe is as it always is - complete and forever transformed into forgetting. And yet it has to be invented and uncovered all over again every day for us to move forward. The purpose of poets and painters is to make the world real by imagining that which exists.

I do not denigrate those who find their way out of the dilemma (or into contemplation) by means of the spiritual or the transcendental, those who may wish to be dissolved in the solution of a Higher Reality, a religion, an ideology or dogma, even if this fearful ecstasy may bring the illusion of an illumination: the adoration of the One that only too often, as idolatrous certainty, leads to an intolerance and even the elimination of the Other. 
Nor do I argue for making or creativeness or transformation or searching for shape as an alternative - or, as a prerequisite, for the art of letting go inherent to remembering and imagination.

What I do know is that we have been striving to experience and understand life ever since the beginning of time - which we cannot know - just as we have to project our non-being one dance step at a time, one rock face at a time, one dawn of time as if it were the first and the last one - one failure at a time, one world at a time, one life at a time - wind by wind and miracle by miracle and bird by bird and darkness by darkness.

This is the lesson our guides of poetry like Master Zbigniew Herbert illuminate: that the word is no remedy for the ailments of the world, and no answer; that it cannot be the representation of reality because it is the reality of being here and now - and thereby the only always we can know. We are our own disappearance. We live to celebrate the unbearable lightness of being, which is the ongoing initiation by imitation of our dying.

In a transcript of A Conversation with Edouard Glissant aboard the Queen Mary II, Manthia Diawara writes (this is Glissant, the late poet-philosopher from Martinique, talking):

The imagination of the world is something else.

It is the intuition of everything that can be touched in the world, everything that's the same and everything that's different. What's different in the world constitutes our strength. I always say the fabric of living and the canvas of cultures are not created on the basis of the similar, but the different. It is the alliance of differences that creates the fabric of the living and the canvas of cultures.

I come from an earth that will be flat again, where the valorisation of diversity is snuffed out by profoundly colonialised political expediency in praise of ignorance and incompetence. It is prescribed that my tongue of many mothers and fathers, of hybridisation, of becoming-other, will fall silent and be swallowed in shame for the past. 'National consensus' decrees that we can no longer allow texture or transgression or uncertainty to nourish our curiosity. All of that will be flattened by the morally correct weight of fear, conformism, populist sloganeering draped in the shroud of nihilism called historical determinism. Or put differently: for the sake of progress and equality, "it is only natural that the majority should have more rights than the minorities," according to President Zuma of 
South Africa. Anything, as long as it is not true transformation, true emancipation, true human agency in the face of an eternity of unfolding, true accountability for the past and the future with a real responsibility toward life.

John Berger the British essayist, artist and poet who recently gave his tongue to silence, wrote in And Our Faces, My Heart, Brief as Photos, that "language is potentially the only human home, the only dwelling place that cannot be hostile to man." Poetry, he added, makes language care. "There is often nothing more substantial to place against the cruelty and indifference of the world than this caring."

It is good to remember the consolation of Berger's words as we gather here to tend to poetry, the strange and 'useless' discipline (certainly without profit) as an evocation of the shaping / remembering / denying... of human awareness - this illusion of life, even if our approach translates as a cry in the dark.

Poetry is a way of being lost in a Middle World as specific and conscious as a dream in a continuum that makes no sense and has been guiding us since the onset of time. And yet this non-existent time manifests itself in a vital aggregate of senses cast in the wonder and the murderous restrictions of appearance where words, paradoxically, mean nothing, where we cling to the shadows of justification suggested and destroyed by rhythm, incantation, metaphor (that shifty old saboteur), by the precise imagination used to midwife a memory of meaning.

Is it all about texture? About the feeling of being alive? But what if we imagine no life? Are we aware of one another in the endlessness of non-being? What if there were no presence, nobody and nothing out there?

We are here though - all of us as makers and markers and products of the artefacts of a time that perhaps never was, with uses that cannot be known or never existed (except in the poem where they became tools to scrape the skin off words); we are here as shadows in a nether world where light does not penetrate - to soundlessly sing the magic of poetry.

We always knew (and it took us a lifetime to be convinced) that magic will not change the equation of living to die. Is that not our human condition? To do is to sing whilst knowing that it makes no difference. Why do we think this unique to the human species? Why would leaves not dance when the wind blows? Who will recognize the agonising joy of singing for nothing, no-where, perhaps for no-one? But we look back and around us and hear the echoes of our cries and songs and believe that we have expressed part of all of us. 
It won't bring us into the ranks of those few who own mankind and almost certainly not to the fold of believers and escape artists. And yet, we enter upon the transformative dialectic of letting go while becoming other, clinging to the flotsam of our words as migrants who never learned how to swim will hold onto their need to survive in the mad ocean of destruction which is creation... which is destruction.

Maybe we constitute that heart of remembering, which is forgetting. Certainly we celebrate while crying for the dead - from an intimate even if inchoate knowledge of solidarity, of identification with all those who knew the soul is a tongue that must consume itself in the burning.

We celebrate the first grunting one-ness that looked to the stars for guidance in the long hunt for sense; we celebrate the nomad who recognized there must be an endlessness to memory, that the Milky Way will flood the earth just beyond our horizon of expectations; we celebrate the alchemist who created the concept of darkness; we celebrate the self-flagellating anchorite walled in silence, she who went to bed with God - and we weep; we celebrate the poet who wrote the world with its scansion of intricate motifs from coloured sand and then blew it all away; we celebrate the poet who was a saint, who was a whore, who saved the mice, who wore spurs or a veil, who killed her lover, who wrote, who stopped writing. We celebrate and we honour (and we deride) the innocent ones who stepped forth from the night of time to die before a firing squad or in an extermination camp. We celebrate and honour and salute the poet for whom life was a sacrifice to freedom even if we know it is a mirage. But freedom is in the going and not the arrival; in the looking, not the finding. "No pienses sino mira," Wittgenstein wrote. Don't 'think.' 'Look'!

When I woke up in the Théatre Polski in Warsaw I was standing before people very much as I would like to imagine myself to be - only to realise I have been dreaming about singing aloud in my sleep. Did I make it clear enough that this was supposed to be all about the incisiveness and absurdity of the intellect and not just a paean to the dead ancestors and the live spirits? I suspect I spent far too much time on the dialogue between my African fetishes - the loquacious parrot and the silent chameleon, on trying to teach stones how to fly...

So much remains to be said then! Among the many gifts of life is an occasion such as this which returns the mind afresh to Polish letters. How indebted we all are, particularly to your poetry reflecting in poignant and lasting ways the turmoil of your people, the struggles lost and won, the pride and the beauty - and 
that many among you, in a communal commitment to the dignity of not just a national destiny but also a shared human fate, resisted the indignity of giving way to the arbitrariness of the barbarian lurking in all of us. One is reminded especially of the value you confer on the duality (or dichotomy) of the human mind and the human spirit. And always your abundant attention to the particular.

How could one imagine Europe - as also other parts of our shared world - without the unforgettable witness of Bruno Schulz? One knows that the making of modernity was imbued with meaning in the work of Joseph Conrad, Gombrowicz, Miłosz, Szymborska (how much that lady continues to teach and show us!); of Aleksander Wat and Ryszard Kapuściński and Adam Zagajewski and Ryszard Krynicki and Jerzy Ilg...

Please forgive me for what can only be a cursory glance at the complexity of Polish literature and arts: Poland has been blessed and cursed - because lucidity is a curse - beyond the reasonable. How can one not have been formed and informed by the visionary Andrzej Wajda?

And then there is, here, Zbigniew Herbert - the 'burning bush' who brought us together for this occasion, who will not allow me to keep quiet.

I bow in gratitude to Katarzyna Herbert: thank you for reminding us of the history of beauty so much still alive in your eyes. And also to the jury members, my peers - Yuri Andrukhovych, Edward Hirsch, Michael Krüger, Jarosław Mikołajewski, Mercedes Monmany and Andrzej Franaszek - who, in their laudable unwisdom, decided to welcome me to this circle of predecessors before whom I stand in awe, but now no longer as a stranger. Allow me to salute these masters of the word : William Merwin, Charles Simic, Ryszard Krynicki, and to remember Lars Gustafsson. They have always been among the teachers to whom I defer for guidance and I have had the privilege to meet some of them, and to laugh together.

You have indeed extended your generosity beyond Europe and America and in so doing lifted the borders of the map of contemporary literature to include other skylines - propitiously, since tonight, the $25^{\text {th }}$ May, we also celebrate Africa Day.

Thank you for making me realize that this too is what it is like to be at home where dream and reality merge - so that I may stand before you as a creole descendant of Europe and Africa and even the East. (My eldest brother, darkest in hue among my siblings, tells me our oermoeder, our maternal ancestor, was from India.) For this is how and why I'm an Afrikaner: denoting, at the very beginning 
of our tribal symbiosis long before the time of infamy, the offspring born from the mating of European outcasts of many tongues and walks in life (sailors, soldiers, craftsmen, gardeners...) shipped to the Cape by the Dutch East India Company to establish a halfway trading station for the ships sailing East in their quest for spices - with the people of many clans and nations who originally inhabited the coasts and the hinterland of southern Africa. Later there would also come political exiles from other Company possessions, adventurers and fortune seekers, explorers with tame monkeys on their shoulders, mercenaries, riff-raff, refugees fleeing religious repression, slaves...

This is how my 'kitchen Dutch' - the only original language hybridized on the continent to call itself 'African' - came about in the mouths of those who had to communicate with the master and among one another, and the many 'foreigners' now born locally who rebelled and transgressed the borders and defied the Company and became nomads to find themselves forged into bastards who'd forget that they were supposed to be European - so as to carry the traces of many mothers and fathers, to be the vector of resistance and struggle and submission and adaptation and metamorphosis: transformed and imagined in the many variants of Afrikaans.

And, therefore, yes: it is as Afrikaner, African, human and citizen of the world that I thank you in all humility for the honour and the privilege of receiving the Zbigniew Herbert Award.

Breyten Breytenbach - Can Ocells, Paris for the Zbigniew Herbert Foundation

25 May 2017 